\title{
Guettardiscyphia zitti sp. n. - a remarkable hexactinellid sponge from the Lower Turonian of the Bohemian Cretaceous Basin
}

\author{
Radek VODRÁŽKKA ${ }^{1, *}$ \\ 1 Czech Geological Survey, Klárov 3, 11821 Prague 1, Czech Republic
}

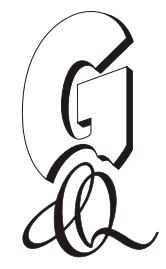

Vodrážka, R., 2017. Guettardiscyphia zittisp. n. - a remarkable hexactinellid sponge from the Lower Turonian of the Bohemian Cretaceous Basin. Geological Quarterly, 61 (3): 632-640, doi: 10.7306/gq.1373

\begin{abstract}
This paper describes a new hexactinosidan hexactinellid Guettardiscyphia zittisp. n. on the basis of a detailed study of 279 specimens from 12 localities in the southern part of the Bohemian Cretaceous Basin. All the studied material comes from the basal Bílá Hora Formation (Lower Turonian). The geology and palaeontology of the sponge-bearing strata at studied locations exhibit identical palaeoenvironmental settings: 1 - transgressive character of sediments with low sedimentation rates, 2 - presence of submarine swells formed by crystalline basement, 3 - hemipelagic sedimentation below the storm-wave base, and 4 - the presence of proliferating diverse sponge faunas with subordinate accompanying macrofaunal remains.
\end{abstract}

Key words: Upper Cretaceous, Turonian, hexactinellid sponge, Guettardiscyphia.

\section{INTRODUCTION}

The Lower Turonian transgressive sediments in the southern margin of the Bohemian Cretaceous Basin (BCB) contain abundant siliceous sponge fauna represented mainly by hexactinellids and lithistid demosponges (e.g., Počta, 1883, 1884). Hexactinellids are represented mainly by hexactinosidan genera Laocoetis Pomel, 1872, Hillendia Reid, 1964 and Guettardiscyphia de Fromentel, 1860; Iychniscosidan hexactinellids are less common (Žítt et al., 2006).

Cribrospongiids, which are characterized by a body with three stellate wings (lobes) and a distinct basidictyonal plate, are one of the most conspicuous hexactinellids occurring at these locations. Počta (1883) found these forms at Kamajka, Zbyslav and Velim and identified them as Guettardia trilobata Roemer (Fig. 1A). However, Pleuroguettardia trilobata (Roemer, 1864) exhibits a different arrangement of canals in the choanosomal skeleton and belongs to the family Craticulariidae Rauff, 1893 (Fig. 1A, for details see the chapter Systematic Palaeontology). Žitt et al. (2006, 2015) depicted this sponge from Chrtníky and Plaňany and identified it as Guettardiscyphia sp., because of its typical cribrospongiid canalization and substantial differences from all known species of Guettardiscyphia. This long-known representative of Guettardiscyphia is de-

\footnotetext{
*E-mail: radek.vodrazka@geology.cz

Received: January 30, 2017; accepted: June 1, 2017; first published online: August 17, 2017
}

scribed herein as a new species $G$. zitti. The description of this new species is based on the study of numerous newly collected specimens from the Bohemian Cretaceous Basin, the vast majority of which were acquired by the author during extensive fieldwork over the past 20 years.

\section{MATERIAL AND METHODS}

All specimens of $G$. zittisp. n. come from 12 locations in the southern part of the BCB (Fig. 2). The examined material comprises 279 specimens: 256 specimens represent material newly collected by the author and deposited in the collections of the Czech Geological Survey (see the Appendix 1*), 19 specimens come from the collections of the National Museum in Prague (for repository numbers see the Appendix 1), and 4 specimens were studied in the collections of the Institute of Geology and Palaeontology of the Faculty of Science (Charles University in Prague).

The largest number of specimens was collected in the Chrtníky active quarry near Heřmanův Městec (e.g., Zágoršek et al., 2009; Žítt et al., 2006, 2014). The second most productive location for the studied species was another active quarry at Plaňany near Kolín (e.g., Žítt and Vodrážka, 2013; Žítt et al., 2015). The Velim, Nová Ves, Radim, Zbyslav, Kamajka and Žehušice locations were already familiar for pioneer Bohemian researchers (e.g., Frič, 1869, 1911; Počta, 1883, 1884, 1885). Other newly collected material is represented by specimens from Nákle, Lipoltice and Markovice (Žítt and Nekvasilová, 1991, 1992) and from the recently described Kolín-Peklo location (Žítt et al., 2013). The geology and age of these sponge- 

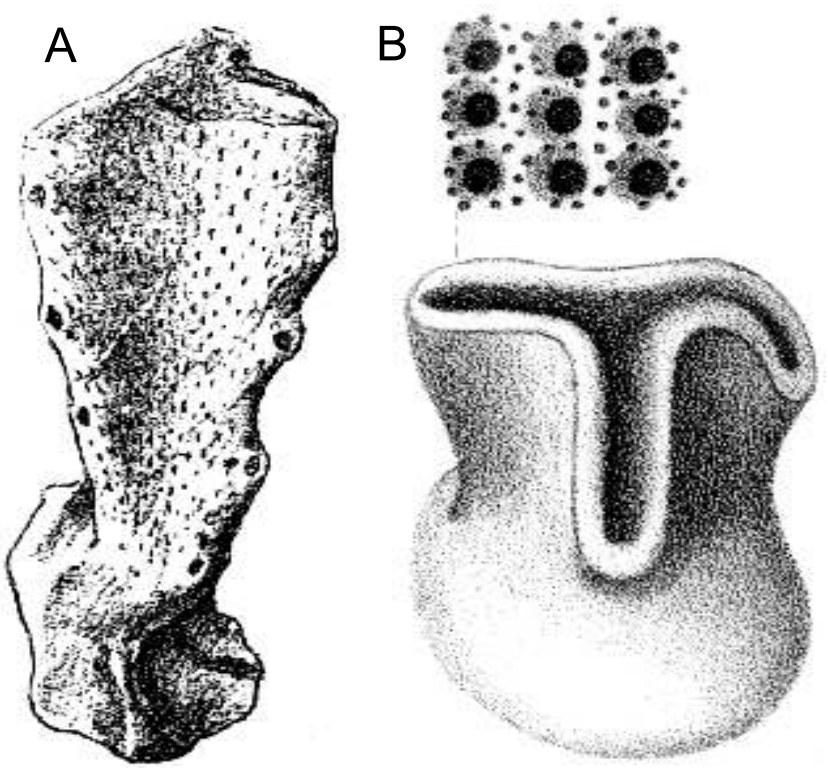

Fig. 1A - original illustration of Počta (1883: p. 23, text, fig. 9) of Guettardia trilobata (Roemer) from Zbyslav (Lower Turonian, Czech Republic) with canals arranged in quincunx; B - original illustration of Roemer (1864: tab. 5, fig. 8) of Pleurostoma trilobatum Roemer = Pleuroguettardia trilobata (Roemer) from Gehrden (Lower Campanian, Germany) with canals arranged in quadrunx -bearing strata exhibit identical lithological characteristics, facies, age, and accompanying macrofauna (see the references above). All the studied material comes from the basal Bílá Hora Formation (Lower Turonian, Whiteinella archaeocretacea and Helvetoglobotruncana helvetica zones - see, e.g., Žítt et al., 2006, 2015). Lower Turonian siltstones at these locations transgress over the remnants of the Upper Cenomanian sediments or directly over the metamorphic basement.

Newly collected material was prepared mechanically and chemically. Various methods of chemical preparation were employed, including the use of sodium carbonate (Bolli, 1952) and $38 \%$ sulphuric acid (Vodrážka, 2009). Silicified sponge skeletons were treated by etching in 3-10\% acetic (Reid, 1958) or hydrochloric acid in order to obtain material for SEM-studies. Silicified skeletons were studied using standard techniques of SEM microscopy (Phillips XL-20, Polish Academy of Sciences, Warsaw; JEOL JSM-6380LV, Charles University, Prague).

The sponge classification used in this paper follows Systema Porifera (Krautter, 2002; Reiswig, 2002), a recognized authoritative reference for sponge taxonomy.

\section{SYSTEMATIC PALAEONTOLOGY}

Phylum Porifera Grant, 1836

Class Hexactinellida Schmidt, 1870

Order Hexactinosida Schrammen, 1903

Family Cribrospongiidae Roemer, 1864

Genus Guettardiscyphia de Fromentel, 1860

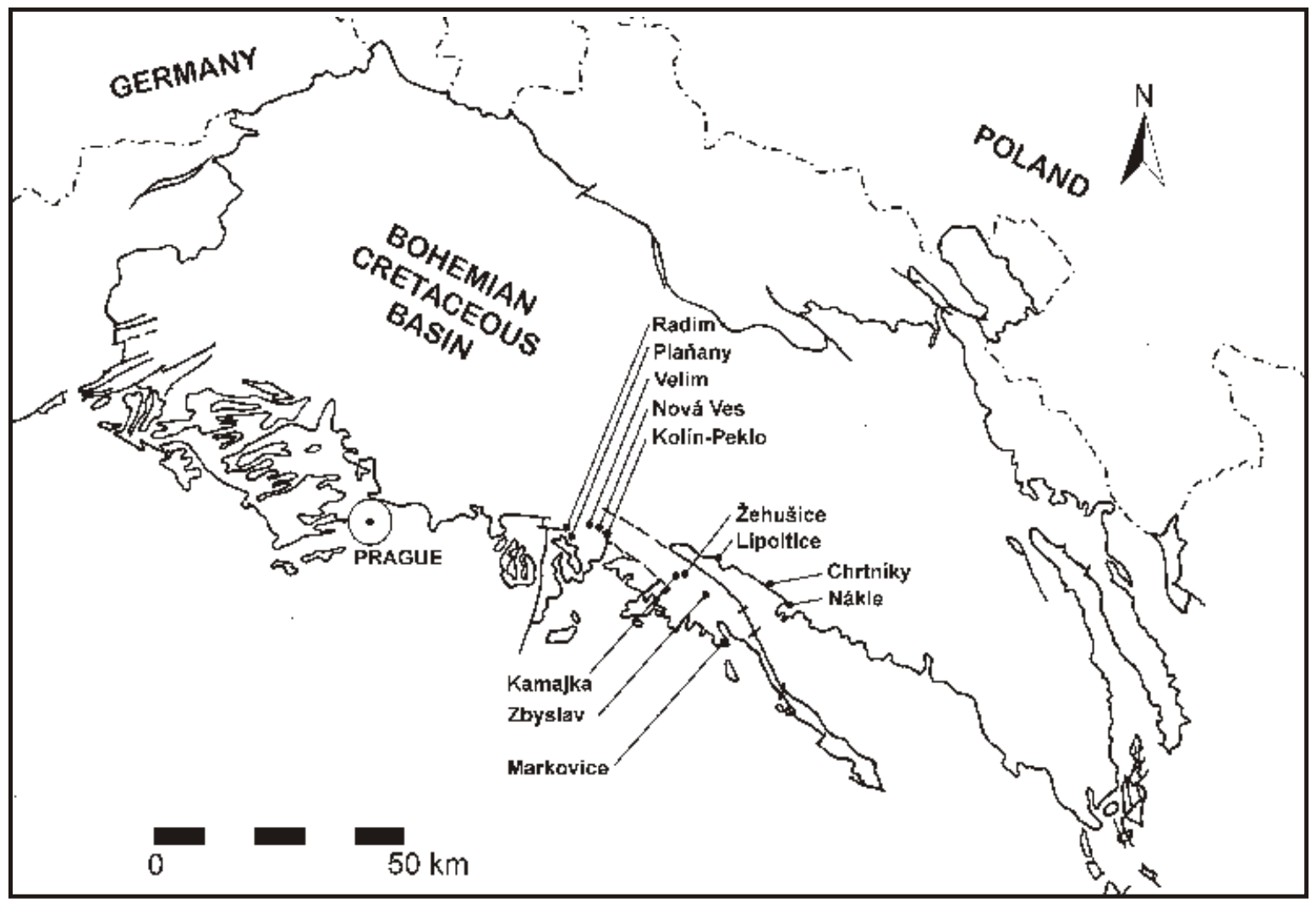

Fig. 2. Geological sketch map showing Upper Cretaceous sediments of the Bohemian Cretaceous Basin with the localities yielding Guettardiscyphia zitti sp. n. indicated (modified after Košt'ák et al., 2010) 
S y n o n y m s. - ?Badinskia Pomel, 1872; Pseudoguettardia Moret, 1925; Koleostoma Regnard, 1926.

E m e n d e d d i a g n o s i s. - Cribrospongiid sponges with wall folded longitudinally above a tubular stalk to form radiate and bilaterally compressed wings or hollow flanges of typically triangular form, which remain connected axially; radial flanges sometimes separate axially, either singly or in pairs, to form blade-like branches; rounded, elliptical or horseshoe-shaped parietal oscula along narrow margins of flanges; flanges freely open at the top, partly closed by transverse bridges of secondary skeletal meshwork, or closed around a single axial osculum.

R e $\mathrm{m}$ a r k s. - Reid (1963) separated the species formerly referred to as Guettardia Michelin, 1844 into two different but homeomorphic genera based on canal organization. One is Guettardiscyphia de Fromentel, 1860 (= Guettardia Michelin, 1844 , non Nardo, 1833), with canals arranged in a quincuncial (cribrospongiid) pattern, and belongs to the Cribrospongiidae Roemer, 1864; the second genus - Pleuroguettardia Reid, 1963 - is characterized by canals arranged in a quadrangular (craticulariid) pattern and belongs to the Craticulariidae Rauff, 1893. It is noteworthy that Reid (2004) considered Pleuroguettardia to be a junior synonym of Ptychocoetis Pomel, 1872. However, Ptychocoetis Pomel, 1872 is nomen nudum and nomen oblitum, whereas Pleuroguettardia Reid, 1963 is considered a valid genus (e.g., Pisera and Besquets, 2002).

Synonymization of Badinskia Pomel, 1872 with Guettardiscyphia de Fromentel, 1860 was proposed by Pisera and Besquets (2002). The genus Badinskia Pomel, 1872 was previously synonymized with Aphrocallistes by Moissette et al. (1984) and Brimaud and Vachard (1986). Pisera and Besquets (2002) interpreted tubular outgrowths figured by Pomel (1872: tab. II bis, figs. 8 and 9) not as tubular branches, as did Moissette et al. (1984) and Brimaud and Vachard (1986), but as probable roots common in Guettardiscyphia. The illustrations and description of Pomel (1872: p. 85) leave no doubt that the tubular outgrowths cannot be interpreted as roots of Guettardiscyphia or any other sponge; the surface of the outgrowths (Pomel, 1872: tab. II bis, figs. 8 and 9) exhibits well-developed regular canalization with quincunx arrangement, which is evidence that the outgrowths represent tubular branches formed by choanosomal skeleton. Moreover, Pomel (1872: tab. II bis, figs. 8 and 9) figured and described transverse sections of tubular outgrowths with a regular radial arrangement of canals of the same type as in his fig. 6, tab. II bis. Synonymization of Badinskia with Guettardiscyphia, as proposed by Pisera and Besquets (2002), is followed with a question mark, because Pomel's description (1872) of the general shape of Badinskia lobata resembles representatives of Guettardiscyphia and Hillendia. The presence of parietal oscula (Pomel, 1872: p. 85) and quincuncially arranged canals (Pomel, 1872: p. 85, 86) are also characteristic for both genera. Important taxonomical characteristics, such as the arrangement of aporhyses, or description of the whole shape of the complete specimen, are lacking in Pomel's (1872) description. The above arguments make the synonymization of Badinskia with Guettardiscyphia doubtful.

T y p e s p e c i e s. - Guettardia stellata Michelin, 1844, p. 121,122 , pl. 30 , figs. 1-11.

\section{Guettardiscyphia zitti sp. n.}

$$
\text { (Figs. 3-5) }
$$

1883 Guettardia trilobata Roem. - Počta, p. 23, text. fig. 9 1911 Guettardia trilobata Röm. - Frič, p. 79, fig. 328 1997 Guettardia trilobata Roem. - Žítt et al., pl. 2, fig. 2
2006 Guettardiscyphia sp. - Žítt et al., fig. 12G, H, K

2015 Guettardiscyphia sp. - Žítt et al., fig. 9I, J

H o I o t y p e. - Specimen RV347-PG49 (Fig. 3A). Housed in the Collections of the Czech Geological Survey, Prague, Czech Republic.

P a r a ty pes. - Specimens RV363-PG65 (Fig. 3B), RV402-NG20 (Fig. 3C), RV391-NG9 (Fig. 3E), RV225-CHG76 (Fig. 3F), RV245-CHG96 (Fig. 4C). Paratypes are housed in the Collections of the Czech Geological Survey, Prague, Czech Republic.

S t u died m a t e ri a l. - 279 specimens from the Bohemian Cretaceous Basin: 12 specimens from the Kamajka location, 3 specimens from Zbyslav, 128 specimens from Chrtníky, 11 specimens from Velim, 8 specimens from Nová Ves, 1 specimen from Lipoltice, 1 specimen from Radim, 6 specimens from Markovice, 2 specimens from Žehušice, 84 specimens from Plaňany, 25 specimens from Nákle, 3 specimens from Kolín-Peklo. The specimen from Zbyslav figured by Počta (1883) and Frič (1911) (specimen NM-O3278, see Appendix 1). Specimens from Velim, Chrtníky and Plaňany, figured by Žítt et al., 1997, 2006, 2015 (see synonymy list), have also been examined. For the age and geology of the localities see the chapter Material and Methods, for their location see Figure 2. For the repositories of the specimens see the Appendix 1.

L o c u s t y p i c u s. - Plaňany Quarry near Kolín, Czech Republic.

Stratum typicum. - Upper Cretaceous, Early Turonian, Mytiloides labiatus Zone. Lower part of the Bílá Hora Formation (sensu Čech et al., 1980).

E t y m o I o g y. - In honour of Jiří Žítt (Institute of Geology of CAS, Prague), a great personage and outstanding research worker, who published major works on geology and palaeontology of the nearshore facies of the Bohemian Cretaceous Basin.

$\mathrm{D}$ i a $\mathrm{g} n$ o $\mathrm{s}$ i s. - The sponge forms typically three stellate wings in its upper part. In its lower part, the sponge skeleton is irregularly lobate or elliptical in cross section and forms a basidictyonal plate on its basal part with occasional root-like outgrowths (secondary deposition of the regular dictyonal framework). Rounded to elliptical parietal oscula occur along the edges of the wings, as well as along the lobate portion of the lower part of the sponge. Epirhyses (i.e. inhalant canals) show a regular quincuncial arrangement of canal openings on the dermal surface; their number varies between 96 and 304 per square centimetre. Aporhyses (i.e. exhalant canals) are in the same arrangement as epirhyses (quincunx), but the gastral side may exhibit twice as many apertures, of which only half are true aporhyses, and the second half are epirhyses extending from the dermal surface.

$\mathrm{D}$ e s c r i p t i o $\mathrm{n}$. - In cross-section, the sponge is stellate in its upper part (e.g., Figs. 3A and 4F) and lobate to elliptical (resp. circular) in its lower part. The upper, stellate portion is composed of three $(96.5 \%$ of specimens), rarely of two $(2.2 \%$ of specimens; Fig. $4 \mathrm{~A}$ ) or four (1.3\% of specimens) laterally compressed wings that originate by radial folding of the walls. These wings are star connected and $3 \mathrm{~mm}$ (juveniles) to $13 \mathrm{~mm}$ (gerontic) thick. Two parallel walls forming a wing are separated by a narrow space. The wall forming a wing has a thickness of $1.3-4.6 \mathrm{~mm}$. In the lower part of the plicated portion, the narrow space between wings is usually filled in by a secondary dictyonal skeleton (Figs. $3 \mathrm{~A}$ and $4 \mathrm{E}-\mathrm{G}$ )

Rounded to eliptical parietal oscula occur along the edges of these wings, as well as along the lobate portion of the lower part of the sponge (e.g., Fig. 4A, C, D). Parietal oscula are $0.8 x$ 0.8 to $10.3 \times 8.4 \mathrm{~mm}$ in diameter (see the Appendix 1) with spacing of 3.5-19 mm; specimens with larger pariatal oscula 


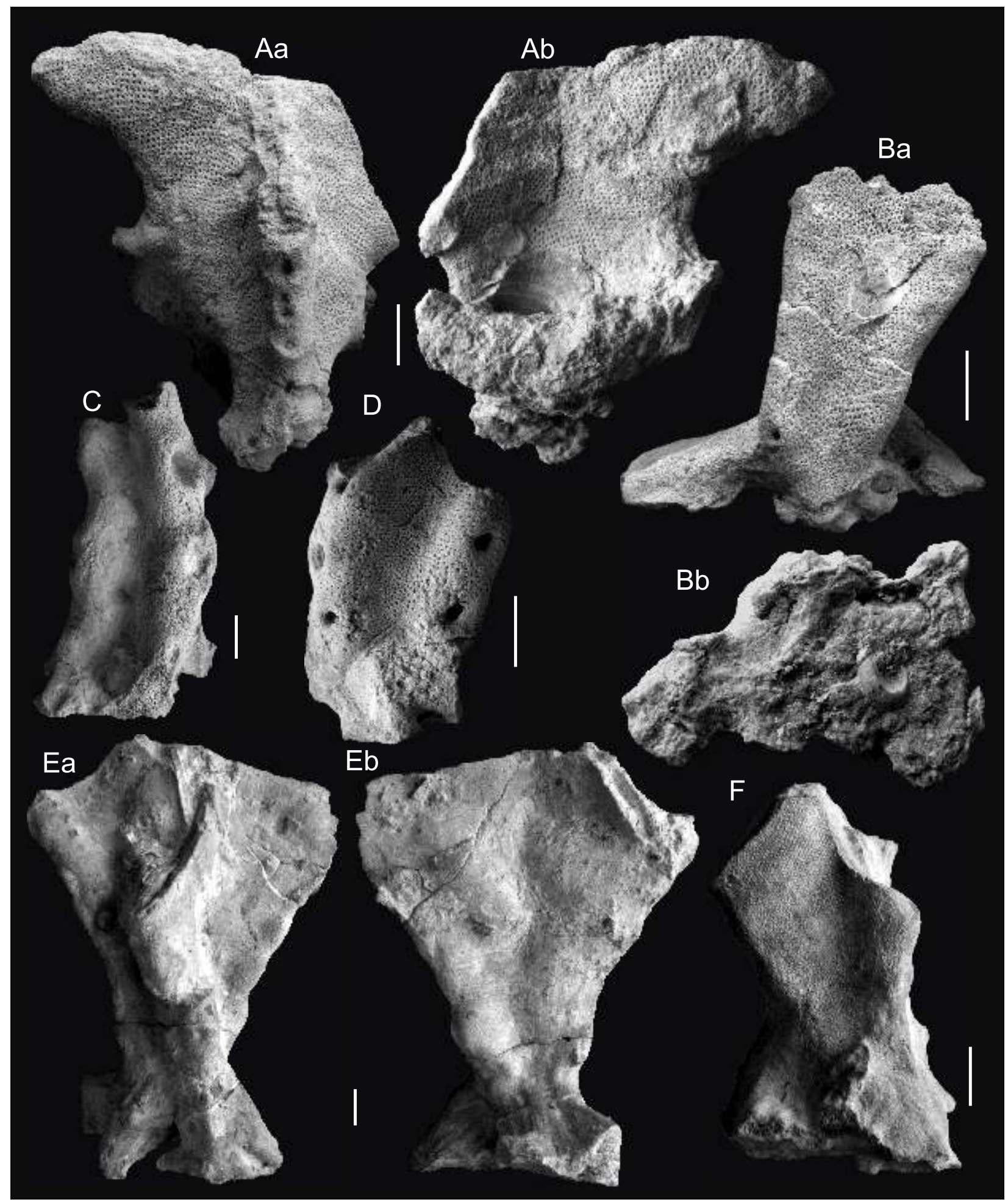

Fig. 3. Guettardiscyphia zitti sp. n.

A - holotype RV347-PG49, Plaňany, note two Spondylus sp. valves cemented near the basidictyonal plate; B - paratype RV363-PG65, Plaňany, note the bivalve Atreta sp. cemented on the attachment surface of the basidyctional plate; C - paratype RV402-NG20 with large parietal oscula along the edges of the wings, Nákle; D - specimen RV224-CHG75 with seemingly irregular distribution of canals due to thickened cortical layer, Chrtníky; E - paratype RV391-NG9, gerontic specimen with rhizobasidyctional plate, Nákle; F - paratype RV225-CHG76, Chrtníky 


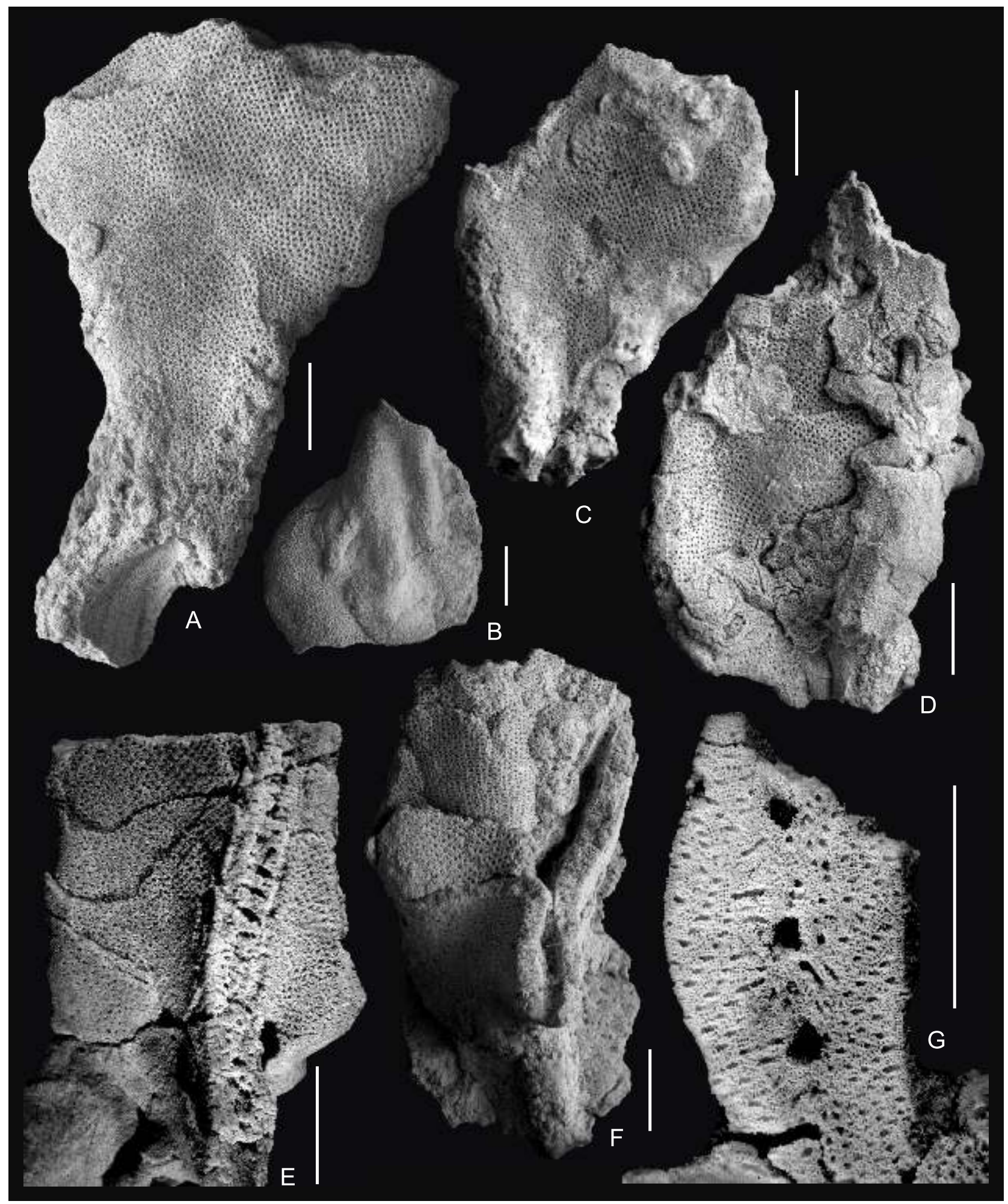

Fig. 4. Guettardiscyphia zitti sp. $\mathrm{n}$.

A - specimen RV226-CHG77 with a small attachment scar having only two developed wings, Chrtníky; B - specimen RV199-CHG50, root-like outgrowths of the basal plate overgrowing lithistid demosponge Chonella sp., Chrtníky; C - paratype RV245-CHG96, carbonate dissolved in acid, Chrtníky; D - specimen RV236-CHG87 overgrown (in the left part) by hexactinellid Cyrtobolia morchella (Reuss), Chrtníky; E - specimen RV178-CHG29, cross-section of a wing in the lower part infilled with a secondary skeleton and closely spaced canals, Chrtníky; F - specimen RV364-PG66 exposing both the gastral surface and the dermal surface of the wall, Plaňany; G - specimen RV155-CHG6, transverse section of the wing showing the primary choanosomal skeleton pierced by epirhyses and aporhyses (left and right part) and wing interior infilled by an irregular secondary framework pierced by smaller and larger canals (central part), carbonate dissolved in acid, Chrtníky 
also exhibit wider interspaces (cf. Fig. 3A, C). Parietal oscula are rounded to elliptical; they usually show parallel elongation with a general direction of sponge growth except in $0.5 \%$ of the specimens under study (see the Appendix 1). Close to the basal part of the sponge, the parietal oscula are usually filled in by accretions of an irregular secondary skeleton.

The studied specimens attach to hard and semi-hard substrates mainly by a broad basidictyonal plate (basiphytous mode of attachment; Figs. 3A, B, F and 4A). The basidictyonal plate is formed by a regular secondary dictyonal skeleton, exhibiting straight dictyonal strands. In addition to a variously shaped basidictyonal plate, some specimens exhibit the presence of root-like outgrowths emitted from the centres of the secondary skeleton deposition (rhizobasiphytous mode of attachment; Figs. 3E, F and 4B).

Inhalant canal openings, situated on the dermal surface of the choanosomal skeleton, are rounded to elliptical. The direction of elongation of inhalant canal openings corresponds to the general direction of growth. The cortex on the dermal surface of the chonaosomal skeleton is well-developed (Fig. 5A). Inhalant canal openings are arranged in a quincunx pattern (Fig. 5A) and are well-exposed typically on the wall surfaces in depressions between the wings (Fig. 4A, B, D). Canal openings on the dermal surface may be seemingly absent in places where they are veiled by a thin layer of secondary dictyonal skeleton, especially close to the edges of the wings as well as close to the basidictyonal plate (Fig. 5E, F). Inhalant canal openings may also exhibit an apparently irregular distribution pattern caused by the presence of a thickened layer of regular secondary dictyonal skeleton (Figs. 3D and 5E). The length of the inhalant canal openings (in the direction of growth of the wall) is $0.22-0.43 \mathrm{~mm}$ and the width equals $0.18-0.42 \mathrm{~mm}$. Inhalant canal openings are separated by skeletal bands, $0.34-0.83$ in width.

The results of 119 measurements (see the Appendix 1) show that the number of epirhyses per square is highly variable - there are 96-304 canal openings per square centimetre with a median value of 175 per $\mathrm{cm}^{2}$. The lowest density of epirhyses (96-128 per $\mathrm{cm}^{2}$ ) was counted exclusively on the distal parts of the wall (e.g., Fig. 3A). In contrast, the highest density counts (240-304 per $\mathrm{cm}^{2}$ ) are located on the walls close to the basidictyonal plate or on juvenile specimens.

Canals inside the chonaosomal skeleton are rounded (Fig. $5 \mathrm{D}$ ), rarely slightly elliptical with elongation parallel to the growth direction. They have a diameter of $0.16-0.36 \mathrm{~mm}$ and distances between their centres equal to $0.35-0.63 \mathrm{~mm}$.

Exhalant canal openings, situated on the gastral surface of the choanosomal skeleton, may be in the same arrangement as the inhalant canal openings (Fig. 5D), or the gastral side exhibits twice as many apertures, of which only half represent aporhyses and the second half are epirhyses extending from the dermal surface (Fig. 4F).

The cortex is not developed on the gastral surface (Fig. 5C, D). The gastral surface within the wings is partly or entirely filled with an irregular secondary dictyonal framework (Fig. 5F). These secondary framework deposits within the wings show the absence of dictyonal strands and are penetrated by irregular smaller and larger canals (Fig. 4E, G) that undoubtedly interconnect the gastral surface with parietal oscula.

The primary (choanosomal) skeleton of the wall exhibits a regular dictyonal framework with distinct dictyonal strands (Fig. $5 B, D, F)$. The frames formed by interconnected hexactines are squared to rectangular, $0.10-0.27 \mathrm{~mm}$ (in the direction of growth) $\times 0.09-0.19 \mathrm{~mm}$ in size. The surface of the spicules is smooth (Fig. 5B), rarely showing fine granulation especially close to the cortex (Fig. 5C). Fine granulation was also observed on hexactines forming the cortical layer.

\section{DISCUSSION}

The skeletal canalization of Guettardiscyphia was first described from Guettardiscyphia (=Koleostoma) godeti (Regnard, 1926: p. 473, 474, pl. XVIII, fig. 1). Moret (1926) established the presence of the same type of structure in the type species $G$. stellata (Michelin). The perforating character of many epirhyses is a special development and suggests that inhalant canals ex tended to the subgastral stratum of the trabecular network (Reid, 1962). Guettardiscyphia stellata (Michelin), Guettardiscyphia godeti (Regnard in Moret), Guettardiscyphia radians (Hinde) and Guettardiscyphia bisalata (Schrammen) are species that exhibit perforating character of the epirhyses. The epirhyses of Guettardiscyphia thiolati (d'Archiac), in contrast, end blindly under the gastral surface of the choanosomal skeleton (Pisera and Besquets, 2002). Guettardiscyphia zitti sp. n., compared with the above-mentioned Guettardiscyphia species, show both perforating and non-perforating character of epirhyses.

Guettardiscyphia thiolati (d'Archiac) differs from Guettardiscyphia zitti sp. n. significantly by skeletal expression of epirhyses and aporhyses inside the choanosomal skeleton. Inside the wall of $G$. thiolati, epirhyses and aporhyses run in one large skeletal space, oval in cross-section, whereas G. zitti sp. n. always shows separate inhalant and exhalant canals (cf. Fig. 5D; Pisera and Besquets, 2002: tab. 12, fig. 3). These two species, however, show similar skeletal characteristics of the wing "infilling" by a secondary skeleton with interconnecting canals (cf. Fig. 4E; Pisera and Besquets, 2002: tab. 7, fig. 8).

Guettardiscyphia zitti sp. n. differs from all the above-mentioned Guettardiscyphia species in typically possessing 3 wings, whereas other representatives of the genus usually bear 4-6 wings. The wings of the newly described species are always united, which is not true for most Guettardiscyphia species (e.g., Guettardiscyphia stellata), which emit separated hollow flanges in the upper part of wings.

Guettardiscyphia zittisp. n. shows the formation of a distinctive basidictyonal/rhizobasidictyonal plate formed by a regular secondary dictyonal framework. Such prominent attachment structures were not described or figured by previous authors in Guettardiscyphia. However, the taxonomical importance of these structures remains questionable, as they might be a response to specific palaeoenvironmental conditions (substrate) at studied locations.

The number of inhalant canal openings per $\mathrm{cm}^{2}$ (representing also the number of epirhyses), which used to be considered an important taxonomical characteristic at the species level (e.g., Schrammen, 1912; Mehl, 1992, was found to be very variable for G. zittisp. n.; 94-304 per $\mathrm{cm}^{2}$ ). Moreover, based on 119 measurements (see the Appendix 1), it can be concluded that the density of canal openings of $G$. zitti strongly depends on the part of the sponge in which the density count was carried out. Therefore, the single number counts of epirhyses per area are not considered a principal taxonomical characteristic for the Guettardiscyphia.

The geology and palaeontology of the sponge-bearing strata at studied locations exhibit identical palaeoenvironmental settings:

- transgressive character of sediments with low sedimentation rates,

- presence of submarine swells formed by the crystalline basement,

- hemipelagic sedimentation below the storm-wave base,

- presence of proliferating diverse sponge faunas with subordinate accompanying macrofaunal remains. 

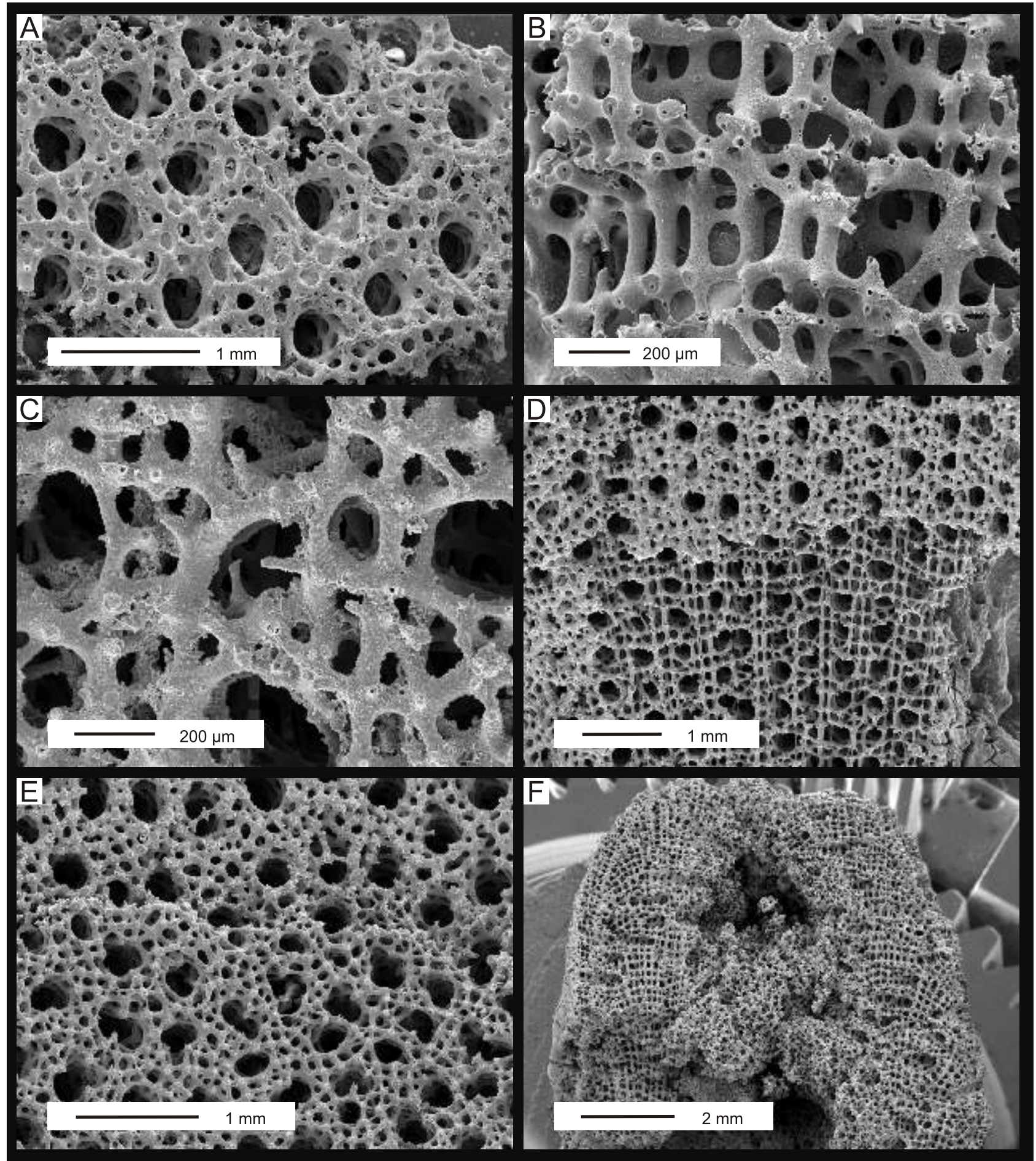

Fig. 5. Guettardiscyphia zitti sp. n., SEM microphotographs of a siliceous skeleton, Chrtníky

A - dermal surface of the wall with quincuncially arranged epirhyses, fragment of RV261-CHG112; B - primary choanosomal skeleton in a transverse section of the wall, fragment of RV261-CHG112; C - gastral surface of the wall with granulated spicules and quadratically arranged epirhyses and aporhyses, fragment of RV235-CHG86; D - gastral surface of the wall with tangential section through the central part of the wall (lower half of the figure), fragment of RV235-CHG86; $\mathbf{E}$ - dermal surface of the wall veiled by a $0.5-\mathrm{mm}$ thick layer of a secondary framework, which was removed in the upper third of the picture, fragment of RV259-CHG110; F - transverse section of the wing, showing the outermost thin layer of a regular secondary framework, wall formed by a regular dictyonal skeleton and the interior of the wing partly infilled by an irregular secondary meshwork, fragment of RV155-CHG6 
This is in conformity with numerous modern studies reporting Late Cretaceous hexactinellid faunas typically linked to transgressive cycles, low sedimentation rates, and depths below the storm-wave base (see e.g., Schneider et al., 2011, 2013; Vodrážka and Crame, 2011 and references therein).

\section{CONCLUSIONS}

All the studied specimens (279 specimens from 12 locations) of G. zittisp. n. come from the basal Bílá Hora Formation in the Bohemian Cretaceous Basin (Lower Turonian). This is a very remarkable sponge, known to Czech scientists since the 19th century (Počta, 1883), but was only recognized as a new species after more than a hundred years. It is concluded that some variable taxonomical characteristics of Guettardiscyphia, such as the density of epirhyses per area, are of limited taxonomical importance.

Acknowledgements. This research was funded by the Grant Agency of the Czech Republic (No. GP14-31662P). In the first place, I would like to thank A. Pisera (Polish Academy of Sciences) for his kind tutoring of my initial research on siliceous sponges from the BCB. J. Žítt (Czech Academy of Sciences), M. Košták (Charles University in Prague) and S. Čech (Czech Geological Survey) are thanked for invaluable discussions on the geology and palaeontology of the studied locations. Thanks go also to J. Sklenár (National Museum in Prague) for access to the National Museum collections and for his assistance during numerous joint field trips. I also wish to thank E. Świerczewska-Gładysz, F. Wiese, T. Peryt and Anonymous Reviewer, whose suggestions and critical remarks helped to improve the manuscript.

\section{REFERENCES}

Bolli, H., 1952. Note on the disintegration of indurated rocks. Micropaleontologist, 6: 46-48.

Brimaud, C., Vachard, D., 1986. Les Spongiaires siliceux du Tortonien des Bétiques (Miocène de l'Espagne du Sud): espèces nouvelles ou peu connues. II. Hexactinellides. Bulletin du Muséum National d'Histoire Naturelle C, 4: 415-445.

Čech, S., Klein, V., Křiž, J., Valečka, J., 1980. Revision of the Upper Cretaceous stratigraphy of the Bohemian Cretaceous Basin. Věstník Ústředního Ústavu Geologického, 55: 277-296.

de Fromentel, M.E., 1860. Introduction a l'étude des éponges fossiles. Mémoires de la Société Linnéenne de Normandie, 11: $1-50$.

Frič, A., 1869. Palaeontologische Untersuchungen der einzelnen Schichten in der böhmischen Kreideformation. Perucer Schichten. Die Korycaner Schichten. Archiv für die naturwissenschaftliche Landesdurchforschung von Böhmen, 1: 181-242.

Frič, A., 1911. Studie v oboru křídového útvaru v Čechách. Ilustrovaný seznam zkamenělin cenomanních vrstev Korycanských (in Czech). Archiv pro Př́rodovědecký Výzkum Čech, 15: 1-101.

Grant, R.E., 1836. Animal Kingdom In: The Cyclopaedia of Anatomy and Physiology, 1 (ed. R.B. Todd): 107-118. Sherwood, Gilbert, Piper, London.

Košt'ák, M., Vodrážka, R., Frank, J., Mazuch, M., Marek, J., 2010. Late Cretaceous nautilid beaks from the near-shore/shallow water deposits of the Bohemian Cretaceous Basin (Czech Republic). Acta Geologica Polonica, 60: 417-428.

Krautter, M., 2002. Fossil Hexactinellida: an overview In: Systema Porifera: a Guide to the Classification of Sponges (eds. J.N.A. Hooper and R.W.M. Van Soest): 1211-1223. Kluwer Academic/Plenum Press, Amsterdam.

Mehl, D., 1992. Die Entwicklung der Hexactinellida seit dem Mesozoikum. Paläobiologie, Phylogenie und Evolutionsökologie. Berliner Geowissenschaftliche Abhandlungen E, 2: 1-164.

Michelin, H., 1844. Iconographie Zoophytologique, Description par Localités et Terrains des Polypiers Fossiles de France et Pays Environnants. P. Bertrand, Paris: 105-144.

Moissette, P., Termier, H., Termier, G., 1984. Quelques précision sur les Spongiaires miocènes de la région d'Oran. Comptes Rendus de l'Académie des Science, 299: 587-592.

Moret, L., 1926. Contribution à l'étude des spongiaires siliceux du Crétacé supérieur français. Bulletin de la Société Géologique de France, 5 .

Nardo, G.D., 1833. Auszug aus einem neuen System der Spongiarien, wornach bereits die Aufstellung in der Universitäts-
-Sammlung zu Padua gemacht ist. Isis, oder Encyclopädische Zeitung Coll.: 519-523. Oken, Jena.

Pisera, A., Besquets, P., 2002. Eocene siliceous sponges from the Ebro Basin (Catalonia, Spain). Geobios, 35: 321-346.

Počta, P., 1883. Beiträge zur Kenntniss der Spongien der böhmischen Kreideformation. I. Abtheilung: Hexactinellidae. Abhandlungen der Königl. Böhmischen Gesellschaft der Wissenschaften, Mathematisch-naturwissenschaftlichen Classe, 4: 1-45.

Počta, P., 1884. Beiträge zur Kenntniss der Spongien der böhmischen Kreideformation. II. Abtheilung: Lithistidae. Abhandlungen der Königl. Böhmischen Gesellschaft der Wissenschaften, Mathematisch-naturwissenschaftlichen Classe, 9: 1-45.

Počta, P., 1885. Beiträge zur Kenntniss der Spongien der böhmischen Kreideformation. III. Abtheilung: Tetractinellidae, Monactinellidae, Calcispongiae, Ceratospongiae, Nachtrag. Abhandlungen der Königl. Böhmischen Gesellschaft der Wissenschaften, Mathematisch-naturwissenschaftlichen Classe, 2: $1-45$.

Pomel, A., 1872. Paléontologie on Description des Animaux Fossiles de la Province d'Oran. Zoophytes. 5é Fascicule, Spongiaires. A.D. Perrier, Oran.

Rauff, H., 1893. Palaeospongiologie. Erster oder allgemeiner Theil und Zweiter Theil, erste Hälfte. Palaeontographica, 40: 1-232.

Regnard, C.H., 1926. Notice sur les Spongiaires cénomaniens de Coulonges-lés-Sablons (Orne). Historique et Hexactinellides. Bulletin de la Société Géologique de France, 4: 469-488.

Reid, R.E.H., 1958. A use for acetic acid in the study of fossil sponges. Geological Magazine, 95: 82-83.

Reid, R.E.H., 1962. Notes on Hexactinellid sponges III. Seven Hexactinosa. Annals and Magazine of Natural History, 13: 739-747.

Reid, R.E.H., 1963. Notes on a classification of the Hexactinosa. Journal of Paleontology, 37: 218-231.

Reid, R.E.H., 1964. Upper Cretaceous Hexactinellida of Great Britain and Northern Ireland, part IV. Palaeontographical Society Monograph, London, 117: xlix-cliv.

Reid, R.E.H., 2004. Mesozoic and Cenozoic hexactinellid sponges: Lyssacinosa and Hexactinosa. In: Treatise on Invertebrate Paleontology (ed. R.L. Kaesler). Pt. E. Porifera, Revised, 3: 449-511. The Geological Society of America and The University of Kansas, Boulder and Lawrence.

Reiswig, H.M., 2002. Family Cribrospongiidae Roemer, 1864 (Recent). In: Systema Porifera: a Guide to the Classification of 
Sponges (eds. J.N.A. Hooper and R.W.M. Van Soest): 1290-1292. Kluwer Academic/ Plenum Press, Amsterdam.

Roemer, F.A., 1864. Die Spongitarien des nordeutschen Kreide-Gebirges. T. Fischer, Cassel.

Schneider, S., Niebuhr, B., Wilmsen, M., Vodrážka, R., 2011. Between the Alb and the Alps - the fauna of the Upper Cretaceous Sandbach Formation (Passau region, southeast Germany). Bulletin of Geosciences, 86: 785-816.

Schneider, S., Jäger, M., Kroh, A., Mitterer, A., Niebuhr, B., Vodrážka, R., Wilmsen, M., Wood, C.J., Zágoršek, K., 2013. Silicified sea life - macrofauna and palaeoecology of the Neuburg Kieselerde Member (Cenomanian to Lower Turonian Wellheim Formation, Bavaria, southern Germany). Acta Geologica Polonica, 63: 555-610.

Schrammen, A., 1903. Zur Systematik der Kieselspongien. Mitteilungen aus dem Roemer Museum, Hildesheim, 19: 1-21.

Schrammen, A., 1912. Die Kieselspongien der oberen Kreide von Nordwestdeutschland. II. Teil Triaxonia (Hexactinellida). Palaeontographica Supplement, 5: 177-385.

Schmidt, O., 1870. Grundzuge einer Spongien-Fauna des atlantischen Gebietes. W. Engelmann, Leipzig.

Vodrážka, R., 2009. A new method for the extraction of macrofossils from calcareous rocks using sulphuric acid. Palaeontology, 52: 187-192.

Vodrážka, R., Crame, J.A., 2011. First fossil sponge from Antarctica and its paleobiogeographical significance. Journal of Paleontology, 85: 48-57.

Zágoršek, K., Taylor, P.D., Vodrážka, R., 2009. Coexistence of symbiotic hydroids (Protulophila) on serpulids and bryozoans in a cryptic habitat at Chrtníky (lower Turonian, Czech Republic). Bulletin of Geosciences, 84: 631-636.

Žítt, J., Nekvasilová, O., 1991. Epibionts cemented to rocky bottom and clasts in the Upper Cretaceous of Železné Hory Mts.
(Czechoslovakia) (in Czech with English summary). Časopis Národního Muzea, Řada Prírodovědná, 156: 17-35.

Žítt, J., Nekvasilová, O., 1992. New occurrences of phosphorites in the Upper Cretaceous of Prague and Kolín lithofacial regions (Czechoslovakia) (in Czech with English summary). Bohemia Centralis, 21: 5-18.

Žítt, J., Vodrážka, R., 2013. Terebella phosphatica Leriche (Polychaeta) associated with phosphatic crusts and particles (Lower Turonian, Bohemian Cretaceous Basin, Czech Republic). Cretaceous Research, 41: 111-126.

Žítt, J., Nekvasilová, O., Bosák, P., Svobodová, M., Štemproková-Jírová, D., Št'astný, M., 1997. Rocky coast facies of the Cenomanian-Turonian Boundary interval at Velim (Bohemian Cretaceous Basin, Czech Republic). First part. Bulletin of the Czech Geological Survey, 72: 83-102.

Žítt, J., Vodrážka, R., Hradecká, L., Svobodová, M., Zágoršek, K., 2006. Late Cretaceous environments and communities as recorded at Chrtníky (Bohemian Cretaceous Basin, Czech Republic). Bulletin of Geosciences, 81: 43-79.

Žítt, J., Vodrážka, R., Svobodová, M., 2013. New data on the Upper Cretaceous near Kolín (Cenral Bohemia) (in Czech with English summary). Zprávy o Geologických Výzkumech v Roce 2012, 2012: 102-108.

Žítt, J., Vodrážka, R., Zágoršek, K., 2014. New observations on the holopodid crinoid genus Cyathidium Steenstrup from the lower Turonian of the Bohemian Cretaceous Basin, Czech Republic. Cretaceous Research, 51: 56-69.

Žítt, J., Vodrážka, R., Hradecká, L., Svobodová, M., Št’astný, M., Švábenická, L., 2015. Depositional and palaeoenvironmental variation of lower Turonian nearshore facies in the Bohemian Cretaceous Basin, Czech Republic. Cretaceous Research, 56: 293-315. 